\title{
Factors Influencing the Concentration of Certain Liposoluble Components in Cow and Goat Milk: A Review
}

\author{
Anamaria COZMA ${ }^{1}$, Doina MIERE ${ }^{1 *}$, Lorena FILIP ${ }^{1}$, Roxana BANC ${ }^{1}$, \\ Oana STANCIU ${ }^{1}$, Sanda ANDREI ${ }^{2}$, Felicia LOGHIN ${ }^{3 *}$
1 "Iuliu Hațieganu" University of Medicine and Pharmacy, Faculty of Pharmacy, Department of Bromatology, Hygiene, Nutrition, 6 Pasteur Street,400349Cluj-Napoca,Romania; anamaria.cozma@umfcluj.ro; dmiere@umfcluj.ro (*correspondingauthor); lfilip@umfcluj.ro; roxana.banc@umfcluj.ro; oana.stanciu@umfcluj.ro 400372 Cluj-Napoca, Romania; sandrei@usamvcluj.ro
3 "Iuliu Hațieganu" University of Medicine and Pharmacy, Faculty of Pharmacy, Department of Toxicology, 6 Pasteur Street, 400349 Cluj- \\ ${ }^{2}$ University of Agricultural Sciences and Veterinary Medicine, Faculty of Veterinary Medicine, Department of Biochemistry, 3-5 Mănăştur Street, \\ Napoca, Romania; floghin@umfcluj.ro (*corresponding author)
}

\begin{abstract}
Milk fat contains a large number of fatty acids (FA) and other liposoluble components that exhibit various effects on human health. The present article reviews some of the factors affecting FA, vitamin A and cholesterol concentrations in milk from dairy cow and goat. Milk fat composition is linked to many factors, both intrinsic (animal species, breed, lactation stage) and extrinsic (environmental). The effect of animal species on milk fat composition is important, as reflected by higher concentrations of shortand medium-chain FA, vitamin A and cholesterol in goat than in cow milk. In a given ruminant species, the effects linked to breed are significant but limited and they can only be achieved over long periods of time. The lactation stage has an important effect on milk FA composition, mainly linked to body fat mobilisation in early lactation, but it only lasts a few weeks each year. Furthermore, changes in feeding have a marked influence on milk fat composition. Changing the forages in the diet of ruminants, pasture in particular, or supplementing lipids to the diet, represent an efficient mean to modify milk fat composition by decreasing saturated FA and cholesterol, and increasing cis-9,trans-11-CLA and vitamin A. Nutrition therefore constitutes a natural strategy to rapidly modulate milk FA, vitamin A and cholesterol composition, with the overall aim of improving the long-term health of consumers.
\end{abstract}

Keywords: milk, fatty acids, vitamin A, cholesterol, health

Introduction

Globally, recent decades have witnessed an increase in milk consumption, due to growing interest in the nutritional value of this animal-derived food (Kliem and Givens, 2011). Besides an important demand for cow milk, there is also an increasing interest in goat milk, considered to have higher digestibility and lower allergenic reactions than cow milk (Bernard et al., 2009).

Fat is one of the most important components of milk, containing a large number of fatty acids (FA) and other liposoluble components that exhibit various effects on human health (Miciński et al., 2012). Butyric acid (4:0), branched-chain FA and cis-9,trans-11-conjugated linoleic acid (CLA) in milk fat have been shown to exhibit anticarcinogenic properties in a number of human cell line cultures and animal models (Cai et al., 2013; Mills et al., 2011). Caproic (6:0), caprylic (8:0) and capric (10:0) acids may reduce the risk of developing features of metabolic syndrome (Nagao and Yanagita, 2010). Oleic acid (cis-918:1) and n-3 polyunsaturated FA (PUFA) together with an optimal $n-6 / n-3$ ratio are considered to be beneficial for cardiovascular health, whereas vitamin A exhibits an important role in vision and immunity (Chávez-Servín et al., 2008; Haug et al., 2007). On the contrast, medium-chain saturated FA (SFA) (12:0, 14:0, 16:0), trans-18:1 FA and cholesterol may contribute to an increase in cardiovascular risk (Baum et al., 2012; Mozaffarian et al., 2009; Viturro et al., 2010).

Furthermore, fat is the most variable component of milk, depending on intrinsic (animal species, breed, genotype, lactation stage) or extrinsic (environmental) factors (Chilliard et al., 2007). These data need to be deepened, in order to know what type of milk has more benefits for the health of consumers from the perspective of milk fat composition. Therefore, the aim of this article was to review some of the factors affecting FA, vitamin A and cholesterol concentrations in milk from cow and goat. 


\section{Influence of breed}

Within a given ruminant species, the differences in milk FA composition linked to breed are significant, but restricted, and they can only be achieved over long periods of time (Chilliard et al., 2007). Moreover, breed differences in milk FA composition are generally minor when compared with the effects of dietary modulation or variations among individual animals (Ferlay et al., 2011).

Under identical feeding conditions, milk fat from Holstein cows had a lower content of 16:0 and a higher content of cis-9-18:1 than milk fat from Jersey cows (Drackley et al., 2001; Palladino et al., 2010). Cis-9,trans11-CLA milk fat concentration was higher in Holstein cows than in Jersey cows $(+0.11 \mathrm{~g} / 100 \mathrm{~g}$ of total FA) (White et al., 2001) and Brown Swiss cows (+0.03 g/100g of total FA) (Kelsey et al., 2003). In contrast, milk fat from Holstein cows had lower cis-9,trans-11-CLA concentration (-0.33 $\mathrm{g} / 100 \mathrm{~g}$ of total FA) than that from Salers cows (Cozma $e t$ al., 2013). Milk fat from Holstein cows was also poorer in odd- and branched-chain FA (OBCFA), but richer in 4:0 and 18:3 n-3 than that from Montbéliarde cows (Ferlay et al., 2010). Moreover, the Tarentaise cows had higher milk percentages of $18: 0(+1.86 \mathrm{~g} / 100 \mathrm{~g}$ of total FA) and 18:3 n-3 $(+0.30 \mathrm{~g} / 100 \mathrm{~g}$ of total FA) and lower percentages of 16:0 ($3.41 \mathrm{~g} / 100 \mathrm{~g}$ of total FA) than the Montbéliarde cows (Ferlay et al., 2006).

Additionally, some data regarding differences in milk FA composition linked to breed are reported also for dairy goats. A study on two goat breeds from Pakistan showed lower milk concentrations of total SFA $(-5.3 \mathrm{~g} / 100 \mathrm{~g}$ of total FA) and higher milk concentrations of cis-9,trans-11CLA (+0.12 g/100g of total FA) for Kamori goats than for Pateri goats (Talpur et al., 2009).

It has been suggested that breed differences in milk FA composition could be due, in part, to the variation of the delta-9 desaturase activity, as reflected by the values of specific product to substrate ratios (cis-9-14:1/14:0, cis-916:1/16:0, and cis-9-18:1/18:0) (Arnould and Soyeurt, 2009).

Regarding vitamin $A$, the concentration of this liposoluble component in milk does not show marked variations among dairy breeds. In this respect, studies on dairy cows reported similar milk vitamin A concentrations for Holstein, Montbéliarde and Tarentaise breeds (Nozière et al., 2006a,b). Nevertheless, slightly higher vitamin A concentrations in the milk fat of Holstein cows $(11.8 \mu \mathrm{g} / \mathrm{g}$ fat) than of Jersey cows $(8.0 \mu \mathrm{g} / \mathrm{g}$ fat $)$ were observed, with Brown Swiss cows $(9.5 \mu \mathrm{g} / \mathrm{g}$ fat) having intermediate concentrations (Nozière et al., 2006b).

For milk cholesterol concentration, the differences observed between dairy breeds are minor or even absent. Thus, no significant differences in milk cholesterol concentration were found between White Thari cows and Red Sindhi cows (Talpur et al., 2006), whereas the average cholesterol concentration in milk fat from Black and White Schleswig-Holsteins cows (246 mg/100 g fat) was reported to be slightly higher than in milk fat from Angler cows (231 $\mathrm{mg} / 100 \mathrm{~g}$ fat) (Precht, 2001).

Influence of lactation stage

The effect of lactation stage on milk FA composition is marked and mainly linked to body fat mobilisation during early lactation stage (Chilliard et al., 2007). At the initiation of lactation, ruminants are in negative energy balance, causing mobilisation of FA from adipose tissue and incorporation of these FA into milk fat (Palmquist et al., 1993). Since the main FA stored in adipose tissue are 18:0 and cis-9-18:1, body lipid mobilisation in early lactation stage induces a sharp increase of these FA concentrations in milk (Chilliard et al., 2003). Thus, milk from the first week of lactation can contain up to $50 \%$ more 18:0 and cis-9-18:1 than the milk from mid-lactation interval (Palmquist et al., 1993). Nevertheless, the lactation stage effect on milk FA composition is transient, lasting only a few weeks ( 6 to 8 weeks) each year (Chilliard and Ferlay, 2004).

Changes in milk vitamin $A$ and cholesterol concentrations in relation to the stage of lactation are poorly documented. Vitamin A has been reported to have much higher concentrations in colostrum than in milk, but these concentrations decrease rapidly during the first week after parturition (Nozière et al., 2006b). Moreover, a study in dairy cows indicated only a slight variation in milk vitamin A concentration during the first 24 weeks of lactation (Jensen et al., 1999).

Immediately after parturition, milk was reported to contain also a high concentration of cholesterol $(600 \mathrm{mg} / \mathrm{g}$ fat), which then showed a rapid decline during the first ten days post partum (Precht, 2001). Nevertheless, milk cholesterol concentration was shown to increase with the progress of lactation stage in dairy cows, from $3.74 \mathrm{mg} / \mathrm{g}$ fat at stage I (6-60 days of lactation) to $4.35 \mathrm{mg} / \mathrm{g}$ fat at stage II (61-210 days of lactation), and then to $4.66 \mathrm{mg} / \mathrm{g}$ fat at stage III (between day 211 and end of lactation) (Strzałkowska et al., 2009).

\section{Influence of diet}

Changes in feeding have a marked influence on ruminant milk fat composition (Chilliard et al., 2007). The most important alterations can be seen either by changing the forages in the diets of ruminants, pasture in particular, or by supplementing lipids to the diet (Chilliard et al., 2007; Ferlay et al., 2013; Nałęcz-Tarwacka et al., 2008).

\section{Influence of the nature of forage}

Despite having a relative low content of lipids, forages represent often the major source of unsaturated FA in ruminant diet (Dewhurst et al., 2006). Fresh grass is a rich source of 18:3 n-3 and compared to mixed winter diets, results in increased milk fat concentrations of 18:0 (+2 $\mathrm{g} / 100 \mathrm{~g}$ of total FA), cis-9-18:1 (+8 g/100 $\mathrm{g}$ of total FA), $18: 3 \mathrm{n}-3(+1 \mathrm{~g} / 100 \mathrm{~g}$ of total FA) and cis-9,trans-11-CLA $(+0.6 \mathrm{~g} / 100 \mathrm{~g}$ of total FA), and decreased 10:0-16:0 concentrations (-13 g/100 g of total FA) (Chilliard et al., 2007).

Furthermore, grass conservation through hay making or ensiling leads to decreases in 18:3 n-3 concentrations, with hay having lower 18:3 n-3 concentrations than grass silage (Dewhurst et al., 2006; Morand-Fehr and Tran, 2001). Nevertheless, milk from hay diets can often be richer in 18:3 n-3 than milk from silage diets, due to higher transfer efficiency from diet to milk with hay than with grass silage (Shingfield et al., 2005). 
In contrast to grass, concentrates and soybean meal are rich in 18:2 n-6 (Morand-Fehr and Tran, 2001). Milk FA composition varies widely according to the range of concentrate in the diet. In a pasture-based diet, increasing the concentrate from 3 to $35 \%$ resulted in increased levels of milk 4:0-14:0, trans-18:1 isomers (except trans-11-18:1) and 18:2 n-6, and decreased cis-9-18:1, trans-11-18:1, cis9,trans-11-CLA and 18:3 n-3 contents (Bargo et al., 2002; Bargo et al., 2006). By contrast, when the concentrate exceeded $60 \%$ in a pasture based diet, an increase in milk fat concentrations of all trans-18:1 isomers (especially trans-1018:1), cis-9,trans-11-CLA and 18:2 n-6, and a decrease in 14:0, 16:0 and 18:0 were observed (Dewhurst et al., 2003). Similar studies conducted on goats showed that changes in milk FA linked to the type of forage and forage/concentrate ratio are consistent with the results reported in dairy cows studies (Chilliard et al., 2007).

Vitamin A in milk derives mainly from ruminant diet, the nature of forage having therefore an important influence also on milk vitamin A concentration (Ferlay et al., 2013; Plozza et al., 2012). Moreover, since a part of milk vitamin $A$ is synthesized from $\beta$-carotene, an association between dietary $\beta$-carotene and the concentration of vitamin $A$ in milk has been suggested (Nozière et al., 2006b).

Fresh grass is one of the richest sources of $\beta$-carotene (ca. $360 \mathrm{mg} / \mathrm{kg} \mathrm{DM}$ ) (Ferlay et al., 2013). Nevertheless, $\beta$ carotene content of grass depends on the grass stage of development and decreases during drying and preservation, due to $\beta$-carotene UV-sensitivity (Graulet et al., 2012; Nozière et al., 2006b). In a study upon dairy cows grazing on a middle mountain prairie composed of low diversified grass, found in a leafy stage, milk concentrations reached 7-8 $\mu \mathrm{g} / \mathrm{g}$ fat for $\beta$-carotene and vitamin A (Graulet et al., 2012). In contrast, $\beta$-carotene and vitamin $A$ concentrations in milk were reported to be lower $(2.5-2.8 \mu \mathrm{g} / \mathrm{g}$ fat) for diets based on grass silage, hay or maize silage, which are poorer in $\beta$-carotene (Ferlay et al., 2013).

Likewise, concentrates are typically poor sources of carotenoides (Nozière et al., 2006b). In agreement with the aforementioned data, the average milk fat concentrations of vitamin $A$ and $\beta$-carotene were reported to be 1.2- and 1.6fold higher, respectively, when milk from dairy cows was produced during the grazing vs. the winter feeding period (Agabriel et al., 2004). Similarly, in dairy goats, vitamin A concentration in milk was higher during the grazing period $(650 \mu \mathrm{g} / 100 \mathrm{DM})$ than during the indoor feeding period (499 $\mu \mathrm{g} / 100 \mathrm{DM})$ (Fedele et al., 2004).

With respect to milk cholesterol, although it is mainly synthesised through processes independent of the ruminant diet, feed chemical composition is shown to affect the concentration of this liposoluble component in milk (Strzałkowska et al., 2010). In this respect, cholesterol concentration was reported to be higher in milk from cows fed fresh grass (261 mg/100 g fat) compared to milk from cows fed hay (236 mg/100 g fat) (Aii et al., 1989).

\section{Influence of diet supplementation with lipids}

Over the last decades, dietary lipid supplementation has been used to increase energy intake and/or modify milk FA composition in ruminants (Chilliard et al., 2007). Supplementation of cow and goat diets with vegetable oils rich in either LA (e.g., sunflower or soybean oils) or ALA (e.g., linseed or rapeseed oils) proved to be an effective mean to enhance the cis-9,trans-11-CLA content of milk fat, as well as to decrease milk fat SFA, particularly 12:0, 14:0 and 16:0 (Bernard et al., 2009; Bouattour et al., 2008; Rego et al., 2009). Furthermore, increases in LA or ALA in milk by vegetable oils supplementation are small or absent, as these PUFA are largely hydrogenated in the rumen (Chilliard et al., 2003; Luna et al., 2008; Rego et al., 2009).

In this respect, it has been assumed that giving lipids in the form of oilseeds or rumen-protected oils, rather than free oils, would limit rumen biohydrogenation of PUFA by restricting microbial access to lipids (Chilliard and Ferlay, 2004; Jensen, 2002). Nevertheless, in goats fed a low forage diet, supplemented with either free oil or whole crude oilseeds, from either sunflower or linseed, PUFA were more significantly increased by free oil than by oilseeds (Chilliard et al., 2003). This result was attributed to a slower release of lipids from seeds, thus increasing their rumen biohydrogenation (Chilliard and Ferlay, 2004).

With regard to rumen-protected lipids, encapsulation of plant oils in a formaldehyde-treated casein layer, proved to be one of the most effective protection processes in achieving ruminal protection of PUFA (Woods and Fearon, 2009). Thus, feeding protected canola/soybean oilseed $(70 / 30 \mathrm{w} / \mathrm{w})$ and protected soybean oilseed/linseed oil $(70 / 30 \mathrm{w} / \mathrm{w})$ to dairy cows at pasture increased the concentration of ALA in milk fat from $<1 \%$ to $2.49 \%$ and $8.45 \%$, respectively (Gulati et al., 2002). Although effective, such a dietary practice has its limitations, because it is expensive and it uses controversial formaldehyde (Chilliard and Ferlay, 2004).

Likewise, diet supplementation with marine lipids, rich in long-chain FA of the n-3 series, is considered a good nutritional strategy for enhancing cis-9,trans-11-CLA, 20:5 n-3 and 22:6 n-3 in milk fat of ruminants (Toral et al., 2010a). When equally added to the ration, marine oils seem more effective than plant oils at increasing milk cis-9,trans11-CLA content, as a result of the potent inhibitory effect of long-chain FA on the ruminal reduction of trans-18:1 to 18:0 (Chilliard and Ferlay, 2004; Toral et al., 2010b). Despite the fact that marine oils are rich in 20:5 n-3 and 22:6 n-3, the transfer rates of these FA from diet to milk are low and typically account for 3-4\% in cows and $4-5 \%$ in goats (Chilliard et al., 2003, Sanz Sampelayo et al., 2007). Low transfers from diet to milk could be caused by the extensive rumen biohydrogenation of these FA and by their preferential incorporation into plasma phospholipids and cholesterol esters (Chilliard et al., 2007).

Supplementation of ruminant diet with lipids has been shown to alter also milk vitamin $A$ and cholesterol concentrations. In dairy cows, supplementation of diet for 21 days with different lipid sources $(300 \mathrm{~g} / \mathrm{d}$ of fish oil, $500 \mathrm{~g} / \mathrm{d}$ of Opal linseed, $500 \mathrm{~g} / \mathrm{d}$ of Szafir linseed, $150 \mathrm{~g} / \mathrm{d}$ of fish oil or $250 \mathrm{~g} / \mathrm{d}$ of Opal linseed, $150 \mathrm{~g} / \mathrm{d}$ of fish oil and $250 \mathrm{~g} / \mathrm{d}$ Szafir linseed) increased milk vitamin A concentration in all dietary treatments by 23 to $183 \%$ (Puppel et al., 2013). Likewise, 28 days of dietary supplementation with linseed $(200 \mathrm{~g} / \mathrm{d})$ in dairy cows, caused an important increase in milk vitamin A concentration $(+0.147 \mathrm{mg} / \mathrm{L})$, as well as a decrease in milk cholesterol concentration (-0.205 g/100 g fat) (Nałęcz- 
270

Tarwacka et al., 2008).

Moreover, cholesterol concentration in milk of cows fed a partial mixed ration supplemented with $5.2 \%$ soybean oil for 120 days was decreased by $0.17 \mathrm{mmol} / \mathrm{L}$ between the beginning and the end of the feeding period (Altenhofer $e t$ al., 2014). Similarly, cholesterol concentration in milk of cows fed a total mixed ration supplemented with linseed (21 $\mathrm{g} /$ day) for seven weeks was reported to be $32 \%$ lower than in milk of controls (Reklewska et al., 2002). Also, gradual addition of $275 \mathrm{~g}$ or $550 \mathrm{~g}$ rapeseed oil, or corresponding quantities of wholemeal from rapeseed, decreased milk cholesterol concentration by 8-13\% (Precht, 2001).

\section{Conclusions}

An overview of the most recent studies regarding the factors that affect milk fat composition has been presented. Milk fat composition is closely linked to factors related to the animal (species, breed, lactation stage), but mainly to nutritional factors. Milk FA, vitamin A and cholesterol concentrations are strongly influenced by the nature of forage (preserved vs. grazed grass) in ruminant diet. Important changes in milk fat composition can also be obtained by supplementing plant lipids to the ruminant diet, leading to a decrease in milk SFA and cholesterol, and an increase in milk cis-9,trans-11-CLA and vitamin A. Overall, it seems clear that diet can constitute a natural strategy to rapidly modulate milk FA, vitamin $\mathrm{A}$ and cholesterol composition with the overall aim of improving the long-term health of consumers.

\section{Acknowledgements}

This paper was published under the frame of European Social Fund, Human Resources Development Operational Programme 2007-2013, project no. POSDRU / $159 / 1.5 / S / 136893$.

\section{References}

Agabriel C, Ferlay A, Journal C, Sibra C, Teissier D, Grolier P, Bonnefoy JC, Rock E, Chilliard Y, Martin B (2004). Composes d'intérêt nutritionnel de laits de grand mélange: teneurs en acides gras et vitamines selon l'altitude et la saison. Renc Rech Ruminants 11:51-54.

Aii T, Takahashi S, Kurihara M, Kume M, Kume S (1989). The effects of offered roughage on cholesterol levels in the milk fat of cows. Jap J Zootechnical Sci 60:671-678.

Altenhofer C, Spornraft M, Kienberger H, Rychlik M, Herrmann J, Meyer HH, Viturro E (2014). Effects of rapeseed and soybean oil dietary supplementation on bovine fat metabolism, fatty acid composition and cholesterol levels in milk. J Dairy Res 81:120-128.

Arnould VM-R, Soyeurt H (2009). Genetic variability of milk fatty acids. J Appl Genet 50:29-39.

Bargo F, Delahoy JE, Schroeder GF, Muller LD (2006). Milk fatty acid composition of dairy cows grazing at two pasture allowances and supplemented with different levels and sources of concentrate. Anim Feed Sci Technol 125:17-31.
Bargo F, Muller LD, Delahoy JE, Cassidy TW (2002). Milk response to concentrate supplementation of high producing dairy cows grazing at two pasture allowances. J Dairy Sci 85:1777-1792.

Baum SJ, Kris-Etherton PM, Willett WC, Lichtenstein AH, Rudel LL, Maki KC, Whelan J, Ramsden CE, Block RC (2012). Fatty acids in cardiovascular health and disease: a comprehensive update. J Clin Lipidol 6(3):216-234.

Bernard L, Shingfield KJ, Rouel J, Ferlay A, Chilliard Y (2009). Effect of plant oils in the diet on performance and milk fatty acid composition in goats fed diets based on grass hay or maize silage. Br J Nutr 101:213-224.

Bouattour MA, Casals R, Albanell E, Such X, Caja G (2008). Feeding soybean oil to dairy goats increases conjugated linoleic acid in milk. J Dairy Sci 91:2399-2407.

Cai Q, Huang H, Qian D, Chen K, Luo J, Tian Y, Lin T, Lin T (2013). 13-Methyltetradecanoic acid exhibits anti-tumor activity on T-Cell lymphomas in vitro and in vivo by downregulating $\mathrm{p}$-AKT and activating caspase-3. PLoS ONE $8(6): e 65308$.

Chávez-Servín JL, Castellote AI, López-Sabater MC (2008). Vitamins $\mathrm{A}$ and $\mathrm{E}$ content in infant milk-based powdered formulae after opening the packet. Food Chem 106:299-309.

Chilliard Y, Ferlay A (2004). Dietary lipids and forages interactions on cow and goat milk fatty acid composition and sensory properties. Reprod Nutr Dev 44:467-492.

Chilliard Y, Ferlay A, Rouel J, Lamberet G (2003). A review of nutritional and physiological factors affecting goat milk lipid synthesis and lipolysis. J Dairy Sci 86:1751-1770.

Chilliard Y, Glasser F, Ferlay A, Bernard L, Rouel J, Doreau M (2007). Diet, rumen biohydrogenation and nutritional quality of cow and goat milk fat. Eur J Lipid Sci Tech 109:828-855.

Cozma A, Martin B, Guiadeur M, Pradel Ph, Tixier E, Ferlay A (2013). Influence of calf presence during milking on yield, composition, fatty acid profile and lipolytic system of milk in Prim'Holstein and Salers cow breeds. Dairy Sci Technol 93:99-113.

Dewhurst RJ, Fisher WJ, Tweed JKS, Wilkins RJ (2003). Comparison of grass and legume silages for milk production. 1. Production responses with different levels of concentrate. J Dairy Sci 86:2598-2611.

Dewhurst RJ, Shingfield KJ, Lee MRF, Scollan ND (2006). Increasing the concentrations of beneficial polyunsaturated fatty acids in milk produced by dairy cows in high-forage systems. Anim Feed Sci Technol 131:168-206.

Drackley JK, Beaulieu AD, Elliott JP (2001). Responses of milk fat composition to dietary fat or nonstructural carbohydrates in Holstein and Jersey cows. J Dairy Sci 84:1231-1237.

Fedele V, Rubino R, Claps S, Manzi P, Marconi S, Pizzoferrato L (2004). Seasonal retinol variation in goat milk associated with grazing compared to indoor feeding. S Afr J Anim Sci 34:165167.

Ferlay A, Glasser F, Martin B, Andueza D, Chilliard Y (2011). Effects of feeding factors and breed on cow milk fatty acid composition: recent data. Bulletin UASVM, Veterinary 
Medicine 68(1):137-145.

Ferlay A, Graulet B, Chilliard Y (2013). Maitrise par l'alimentation des teneurs en acides gras et en composes vitaminiques du lait de vache. INRA Prod Anim 26(2):177192.

Ferlay A, Martin B, Lerch S, Gobert M, Pradel Ph, Chilliard Y (2010). Effects of supplementation of maize silage diets with extruded linseed, vitamin $\mathrm{E}$ and plant extracts rich in polyphenols, and morning v. evening milking on milk fatty acid profiles in Holstein and Montbéliarde cows. Animal 4:627-640.

Ferlay A, Martin B, Pradel Ph, Coulon JB, Chilliard Y (2006). Influence of grass-based diets on milk fatty acid composition and milk lipolytic system in Tarentaise and Montbéliarde cow breeds. J Dairy Sci 89:4026-4041.

Graulet B, Piquet M, Duriot B, Pradel P, Hulin S, Cornu A, Portelli J, Martin B, Farruggia A (2012). Variations des teneurs en micronutriments de l'herbe de prairies de moyenne montagne et transfert au lait. Fourrages 209:59-68.

Gulati SK, May C, Wynn PC, Scott TW (2002). Milk fat enriched in n-3 fatty acids. Anim Feed Sci Technol 98:143152.

Haug A, Hostmark AT, Harstad OM (2007). Bovine milk in human nutrition - a review. Lipids Health Dis 6:25.

Jensen RG (2002). The composition of bovine milk lipids: January 1995 to December 2000. J Dairy Sci 85:295-350.

Jensen SK, Johannsen AK, Hermansen JE (1999). Quantitative secretion and maximal secretion capacity of retinol, betacarotene and alpha-tocopherol into cows' milk. J Dairy Res 66(4):511-522.

Kelsey JA, Corl BA, Collier RJ, Bauman DE (2003). The effect of breed, parity, and stage of lactation on conjugated linoleic acid (CLA) in milk fat from dairy cows. J Dairy Sci 86:2588-2597.

Kliem KE, Givens DI (2011). Dairy products in the food chain: their impact on health. Annu Rev Food Sci Technol 2:21-36.

Luna P, Bach A, Juarez M, De la Fuente MA (2008). Effect of a diet enriched in whole linseed and sunflower oil on goat milk fatty acid composition and conjugated linoleic acid isomer profile. J Dairy Sci 91:20-28.

Miciński J, Zwierzchowski G, Kowalski IM, Szarek J, Pierożyński B, Raistenskis J (2012). The effects of bovine milk fat on human health. Polish Annals of Medicine 19:170-175.

Mills S, Ross RP, Hill C, Fitzgerald GF, Stanton C (2011). Milk intelligence: Mining milk for bioactive substances associated with human health. Int Dairy J 21(6):377-401.

Morand-Fehr P, Tran G (2001). La fraction lipidique des aliments et les corps gras utilisés en alimentation animale. INRA Prod Anim 14:285-302.

Mozaffarian D, Aro A, Willett WC (2009). Health effects of trans-fatty acids: experimental and observational evidence. Eur J Clin Nutr 63:5-21.

Nagao K, Yanagita T (2010). Medium-chain fatty acids: Functional lipids for the prevention and treatment of the metabolic syndrome. Pharmacol Res 61:208-212.

Nałęcz-Tarwacka T, Grodzki H, Kuczyńska B (2008). Usefulness of linseeds for the modification of fat fraction components in cow milk. Medycyna Wet 64(1):85-87.

Nozière P, Graulet B, Lucas A, Martin B, Grolier P, Doreau M (2006b). Carotenoids for ruminants: From forages to dairy products. Anim Feed Sci Technol 131:418-450.

Nozière P, Grolier P, Durand D, Ferlay A, Pradel P, Martin B (2006a). Variations in carotenoids, fat-soluble micronutrients, and color in cow's plasma and milk following changes in forage and feeding level. J Dairy Sci 89:2634-2648.

Palladino RA, Buckley F, Prendiville R, Murphy JJ, Callan J, Kenny DA (2010). A comparison between Holstein-Friesian and Jersey dairy cows and their F1 hybrid on milk fatty acid composition under grazing conditions. J Dairy Sci 93:21762184.

Palmquist DL, Beaulieu AD, Barbano DM (1993). Feed and animal factors influencing milk fat composition. J Dairy Sci 76:1753-1771.

Park YW, Juárez M, Ramos M, Haenlein GFW (2007). Physico-chemical characteristics of goat and sheep milk. Small Ruminant Res 68:88-113.

Plozza T, Trenerry VC, Caridi D (2012). The simultaneous determination of vitamins $A, E$ and $\beta$-carotene in bovine milk by high performance liquid chromatography-ion trap mass spectrometry (HPLC-MSn). Food Chem 134:559563.

Precht D (2001). Cholesterol content in European bovine milk fats. Nahrung/Food 45(1):2-8.

Puppel K, Nałęcz-Tarwacka T, Beata Kuczyńska B, Gołębiewski M, Kordyasz M (2013). Effect of different fat supplements on the antioxidant capacity of cow's milk. Archiv Tierzucht 56:17.

Rego OA, Alves SP, Antunes LM, Rosa HJ, Alfaia CF, Prates JA, Cabrita AR, Fonseca AJ, Bessa RJ (2009). Rumen biohydrogenation-derived fatty acids in milk fat from grazing dairy cows supplemented with rapeseed, sunflower, or linseed oils. J Dairy Sci 92(9):4530-4540.

Reklewska B, Oprzadek A, Reklewski Z, Panicke L, Kuczyńska B, Oprzadek J (2002). Alternative for modifying the fatty acid composition and decreasing the cholesterol level in the milk of cows. Livest Prod Sci 76(3):235-243.

Sanz Ceballos L, Ramos Morales E, De la Torre Adarve G, Díaz Castro J, Pérez Martínez L, Sanz Sampelayo MR (2009). Composition of goat and cow milk produced under similar conditions and analyzed by identical methodology. J Food Comp Anal 22:322-329.

Sanz Sampelayo MR, Chilliard Y, Schmidely Ph, Boza J (2007). Influence of type of diet on the fat constituents of goat and sheep milk. Small Ruminant Res 68:42-63.

Shingfield KJ, Chilliard Y, Toivonen V, Kairenius P, Givens DI (2008). Trans fatty acids and bioactive lipids in ruminant milk. Adv Exp Med Biol 606:3-65.

Shingfield KJ, Salo-Väänänen P, Pahkala E, Toivonen V, Jaakkola S, Piironen V, Huhtanen P (2005). Effect of forage conservation method, concentrate level and propylene glycol on the fatty acid composition and vitamin content of cows' 
272

milk. J Dairy Res 72(3):349-361.

Strzałkowska N, Jóźwik A, Bagnicka E, Krzyżewski J, Cooper RG, Horbańczuk JO (2009). Studies upon genetic and environmental factors affecting the cholesterol content of cow milk. I. Relationship between the polymorphic form of beta-lactoglobulin, somatic cell count, cow age and stage of lactation and cholesterol content of milk. Anim Sci Pap Rep 27(2):95-103.

Strzałkowska N, Jóźwik A, Bagnicka E, Krzyżewski J, Cooper RG, Horbańczuk JO (2010). Factors affecting the cholesterol content of milk of cows fed conserved feeds in a TMR system throughout the year. Mljekarstvo 60(4):273279.

Talpur FN, Bhanger MI, Khuhawar MY (2006). Comparison of fatty acids and cholesterol content in the milk of Pakistani cow breeds. J Food Comp Anal 19:698-703.

Talpur FN, Bhanger MI, Memon NN (2009). Milk fatty acid composition of indigenous goat and ewe breeds from Sindh, Pakistan. J Food Comp Anal 22:59-64.
Toral PG, Frutos P, Hervas G, Gomez-Cortes P, Juarez M, de la Fuente MA (2010a). Changes in milk fatty acid profile and animal performance in response to fish oil supplementation, alone or in combination with sunflower oil, in dairy ewes. J Dairy Sci 93:1604-1615.

Toral PG, Hervas G, Gomez-Cortes P, Frutos P, Juarez M, de la Fuente MA (2010b). Milk fatty acid profile and dairy sheep performance in response to diet supplementation with sunflower oil plus incremental levels of marine algae. J Dairy Sci 93:1655-1667.

Viturro E, Meyer HH, Gissel C, Kaske M (2010). Rapid method for cholesterol analysis in bovine milk and options for applications. J Dairy Res 77:85-89.

White SL, Bertrand JA, Wade MR, Washburn SP, Green Jr JT, Jenkins TC (2001). Comparison of fatty acid content of milk from Jersey and Holstein cows consuming pasture or a total mixed ration. J Dairy Sci 84:2295-2301.

Woods VB, Fearon AM (2009). Dietary sources of unsaturated fatty acids for animals and their transfer into meat, milk and eggs: A review. Livest Sci 126:1-20. 